American Journal of Applied Sciences 2 (9): 1337-1342, 2005

ISSN 1546-9239

(C) 2005 Science Publications

\title{
Indigenous Methods in Preserving Bush Mango Kernels in Cameroon
}

\author{
Zac Tchoundjeu, Alain Rene Atangana and Ann Degrande \\ ICRAF/African Humid Tropics, P.O. Box 2067, Yaoundé, Cameroon
}

\begin{abstract}
Traditional practices for preserving Irvingia wombolu and Irvingia gabonensis (bush mango) kernels were assessed in a survey covering twelve villages (Dongo, Bouno, Gribi [East], Elig-Nkouma, Nkom I, Ngoumou [Centre], Bidjap, Nko'ovos, Ondodo [South], Besong-Abang, Ossing and Kembong [Southwest]), in the humid lowland forest zone of Cameroon. All the interviewed households that own trees of species were found to preserve kernels in periods of abundance, excluding Elig-Nkouma (87.5\%). Eighty nine and $85 \%$ did so in periods of scarcity for I. wombolu and I. gabonensis respectively. Seventeen and twenty-nine kernel preservation practices were recorded for $I$. wombolu and I. gabonensis respectively. Most were based on continuous heating of the kernels or kernel byproducts (cakes). The most commonly involved keeping the sun-dried kernels in a plastic bag on a bamboo rack hung above the fireplace in the kitchen. A $78 \%$ of interviews households reported preserving I. wombolu kernels for less than one year while $22 \%$ preserved it for more than one year with $1.9 \%$ for two years, the normal length of the off-season period for trees in the wild. Cakes wrapped with leaves and kept on a bamboo rack hung over the fireplace were reported by households in the East and South provinces to store Irvingia gabonensis longer (more than one year). Further studies on the utilization of heat for preserving and canning bush mango kernels are recommended.
\end{abstract}

Key words: Bush mango, preservation, kernels

\section{INTRODUCTION}

Tropical moist forests are known to be the earth's reservoir of carbon and play an important role in maintaining and enhancing environmental quality. In southern Cameroon, the humid lowlands are dominated by tropical moist forests. Owing to demographic pressures on land resources and exploitation of its rich flora, the humid lowlands of Cameroon are gradually being deforested. Many forest conservation initiatives have been launched, but to be sustainable, the management of tropical moist forests must take into account the needs of the local people who depend on the forest as a source of food, condiment, medicine and raw materials. Domestication of indigenous fruit trees can help to tackle this problem ${ }^{[1,2]}$.

Domestication is an iterative process that includes the selection of the species to be domesticated through socioeconomic studies, germplasm collection and genetic improvement ${ }^{[3]}$. In the tropics of Africa, tree domestication is executed by ICRAF (World Agroforestry Centre) and its partners as a friendlyenvironmental farmer-driven and market-led process matching intraspecific diversity of high-value trees to the needs of subsistence farmers and producemarkets ${ }^{[4]}$. In a farmer survey based on the priorities of subsistence farmers and national researchers ${ }^{[5]}$, Irvingia gabonensis was identified as the top priority species for domestication in humid West Africa.
Irvingia gabonensis and Irvingia wombolu Vermoesen $^{[6]}$ (previously identified as Irvingia gabonensis var excels $a^{[7]}$ ) are indigenous fruit trees originating in West and Central Africa. The geographic range of Irvingia wombolu is from Senegal to Uganda while that of Irvingia gabonensis is from Nigeria to Congo $^{[4]}$. The fruits of I. wombolu and I. gabonensis are similar in appearance to that of cultivated mango (Mangifera indica) and their color varies from green to yellow when mature ${ }^{[4,7]}$. I. gabonensis flowers in February-March and fruits of the rainy season (JulySeptember) while I. wombolu flowers in October and fruits in the dry season (January-March ${ }^{[5,8]}$ ).

I. gabonensis has edible fruits while I. wombolu has inedible ones. The kernels of both species are used as a condiment in soups, increasing their viscosity and drawability ('sliminess'), but $I$. wombolu is preferred due to its better sliming qualities ${ }^{[9]}$. Consequently, $I$. wombolu kernels fetch high prices in cross-border trade $^{[10,11]}$. The trade of the kernels of both species from Cameroon to neighboring countries (Nigeria, Gabon, Equatorial Guinea and Central African Republic) has been valued at US\$260, 000 per annum ${ }^{[12]}$. A comparison of the nutritive qualities of the kernels of both species (Table 1) indicates that $I$. wombolu is more energy-rich due to its higher fat percentage although both species are a good source of oil. The fat from $I$. wombolu kernels have lower iodine and saponification values $^{[13,14]}$. However, the percentage of crude protein is low for the two species (near 7\%).

Corresponding Author: Zac Tchoundjeu, ICRAF/African Humid Tropics, P.O. Box 2067, Yaoundé, Cameroon, Tel: 237 223 75 60, Fax: 2372237440 
Am. J. Applied Sci., 2 (9):1337-1342, 2005

Table 1: Percent proximate composition of fresh defatted kernels from Irvingia $\operatorname{spp}^{[15]}$

\begin{tabular}{lrlclcccc}
\hline & Moisture & Fat & Total carbohydrates & Ash & Crude protein & Crude fibre & Vit. C $(\mathrm{mg} / 100 \mathrm{~g})$ & Vit. A (mg/100g) \\
\hline I. wombolu & 11.90 & 51.3 & 26.02 & 2.46 & 7.42 & 0.86 & 9.24 & 0.63 \\
I. gabonensis & 12.80 & 37.04 & 26.41 & 2.32 & 7.07 & 1.22 & 12.32 & 0.62 \\
\hline
\end{tabular}

Table 2: Descriptive variables of the study sites

\begin{tabular}{|c|c|c|c|c|c|c|c|}
\hline Province & Village & Ethnic group & $\begin{array}{l}\text { Latitude } \\
\left({ }^{\circ} \mathrm{N}\right)\end{array}$ & $\begin{array}{l}\text { Longitude } \\
\left({ }^{\circ} \mathrm{E}\right)\end{array}$ & $\begin{array}{l}\text { Population } \\
\text { density }\end{array}$ & $\begin{array}{l}\text { Degradation of } \\
\text { forest }\end{array}$ & $\begin{array}{l}\text { Market } \\
\text { access }\end{array}$ \\
\hline \multirow[t]{3}{*}{ Centre } & Nkom I & Menguisa & $4^{\circ} 25^{\prime}$ & $11^{\circ} 23^{\prime}$ & High & High & High \\
\hline & Elig-Nkouma & Eton & $4^{\circ} 07$ & $11^{\circ} 24^{\prime}$ & High & High & Medium \\
\hline & Ngoumou & Ewondo & $3^{\circ} 36^{\prime}$ & $11^{\circ} 19^{\prime}$ & High & Medium & High \\
\hline \multirow[t]{3}{*}{ East } & Dongo & Boblis & $4^{\circ} 41^{\prime}$ & $13^{\circ} 26^{\prime}$ & Medium & Medium & High \\
\hline & Bouno & Kako & $4^{\circ} 02^{\prime}$ & $14^{\circ} 59^{\prime}$ & Low & Low & Very low \\
\hline & Gribi & Mbimo & $3^{\circ} 42^{\prime}$ & $15^{\circ} 08^{\prime}$ & Low & Low & Very low \\
\hline \multirow[t]{3}{*}{ South } & Bidjap & Ntumu & $2^{\circ} 26^{\prime}$ & $10^{\circ} 42^{\prime}$ & Low & Low & Very low \\
\hline & Nko'ovos II & Bulu & $2^{\circ} 56^{\prime}$ & $11^{\circ} 21^{\prime}$ & Medium & Medium & High \\
\hline & Ondodo & Bulu & $2^{\circ} 41^{\prime}$ & $11^{\circ} 40^{\prime}$ & Low & Low & Very low \\
\hline \multirow[t]{3}{*}{ Southwest } & Ossing & Ejagham & $5^{\circ} 37^{\prime}$ & $9^{\circ} 19^{\prime}$ & High & Low & High \\
\hline & Kembong & Ejagham & $5^{\circ} 38^{\prime}$ & $9^{\circ} 14^{\prime}$ & High & Medium & High \\
\hline & Besong-Abang & Ejagham & $5^{\circ} 42^{\prime}$ & $9^{\circ} 17^{\prime}$ & High & High & High \\
\hline
\end{tabular}

Owing to seasonality and the variable yield from year to year, farmers store bush mango kernels in order to (i) satisfy household consumption all year round and (ii) sell surplus stock off-season (when the price is higher). The off-season period basically lasts for two years for trees in the wild. Two questions arise from this situation:

Do farmers satisfy household consumption needs and market demand of bush mango throughout the year, especially during the off-season period?

Do indigenous practices for preserving bush mango kernels and kernel by-products alter their nutritive quality?

Although the nutritive quality of I. gabonensis kernels have been investigated ${ }^{[16,17]}$, there is still little knowledge about the nutritive quality of $I$. wombolu at the village level and the impact of indigenous practices of preserving bush mango kernels on their nutritive quality. During the fieldwork, samples of stored bush mango kernels and kernel by-products were collected for future chemical analysis. However, the results are not yet available.

This study attempts to respond to the first question above by investigating the different indigenous practices for preserving bush mango kernels at farmers' level.

\section{MATERIALS AND METHODS}

The study was carried out in four (Southwest, South, Centre and East) provinces of the humid lowlands of Cameroon. This zone is characterized by altitudes below $1000 \mathrm{~m}$ with annual rainfall above 1500 $\mathrm{mm}$, except for the Southwest where annual rainfall is between 3000 and $5000 \mathrm{~mm}$. The rainfall pattern is unimodal in the Southwest with one rainy season peaking in August-September. In the Centre, South and East provinces, the rainfall pattern is bimodal with two rainy seasons occurring from mid-March to mid-July and from mid-August to mid-September.

Study villages were chosen using information, collected during a rapid reconnaissance survey in December 2000-January 2001, in particular areas where people usually collect and use $I$. gabonensis and $I$. wombolu kernels. From this survey, 12 villages in four provinces were selected (Table 2). Except for three villages in the South Province (Bidjap, Nko'ovos II, Ondodo) and Ngoumou in Centre Province, all the villages had both species.

A total of 240 households (20 households randomly sampled per village) were interviewed using a questionnaire focused on: (i) the availability (or the presence) of I. gabonensis and I. wombolu trees on their farms, (ii) whether they extract the kernels or not and how the volume extracted varies between periods of high and low yields, (iii) the storage of kernels (do they usually store the kernels or not and for what purpose?), (iv) the amount stored and the method of storage, (v) the processing of kernels (cake, oil extraction) before storage and (vi) the duration of storage.

As the interviews took place during the fruiting period, processing and storage methods were observed and recorded by the interviewer. Samples of kernels preserved in different ways were also collected for further chemical analyses. Statistical analyses were performed using Genstat 5 (4.1).

\section{RESULTS AND DISCUSSION}

Excluding the South province and Ngoumou, the two species occurred at all study sites. The difference in the durability of the kernels is exploited in many dishes but overall, I. wombolu kernels are preferred due to their better sliming qualities. Therefore, farmers tend to have at their disposal a basic amount of kernels of both species to diversify their nutrition. 
Table 3: Ownership and number (average, min and max) of Irvingia wombolu and Irvingia gabonensis trees in the study sites (20 households

\begin{tabular}{|c|c|c|c|c|c|c|c|}
\hline \multirow[t]{2}{*}{ Province } & \multirow[t]{2}{*}{ Village } & \multicolumn{2}{|c|}{$\begin{array}{l}\% \text { of households having } \\
\text { the species in their farm }\end{array}$} & \multicolumn{2}{|c|}{$\begin{array}{l}\text { Average number of } \\
\text { trees per household }\end{array}$} & \multicolumn{2}{|c|}{$\begin{array}{l}\text { Minimum and maximum number } \\
\text { of trees per household }\end{array}$} \\
\hline & & I. gabonensis & I. wombolu & I. gabonensis & I. wombolu & I. gabonensis & I. wombolu \\
\hline \multirow[t]{3}{*}{ Centre } & Nkom I & 5 & 45 & 0 & 1 & $0-1$ & $0-2$ \\
\hline & Elig-Nkouma & 80 & 15 & 2 & 0 & $0-5$ & $1-3$ \\
\hline & Ngoumou & 85 & - & 4 & - & $0-11$ & - \\
\hline \multirow[t]{3}{*}{ East } & Dongo & 95 & 20 & 3 & 0 & $0-8$ & $0-3$ \\
\hline & Bouno & 95 & 40 & 8 & 2 & $1-40$ & $0-20$ \\
\hline & Gribi & 95 & 100 & 6 & 3 & $0-20$ & $1-15$ \\
\hline \multirow[t]{3}{*}{ South } & Bidjap & 100 & - & 9 & - & $2-22$ & - \\
\hline & Nko'ovos II & 100 & - & 16 & - & $1-56$ & - \\
\hline & Ondodo & 100 & - & 6 & - & $1-20$ & - \\
\hline \multirow[t]{3}{*}{ Southwest } & Ossing & 100 & 100 & 25 & 25 & $7-70$ & $4-123$ \\
\hline & Kembong & 100 & 100 & 18 & 59 & $0-58$ & $3-505$ \\
\hline & Besong-Abang & 100 & 100 & 13 & 24 & $1-100$ & $2-220$ \\
\hline
\end{tabular}

Table 4: Distribution of Irvingia wombolu (I w) and Irvingia gabonensis (I g) trees on farmers' land (20 households per village)

\begin{tabular}{|c|c|c|c|c|c|c|c|c|c|}
\hline \multirow[t]{3}{*}{ Province } & \multirow[t]{3}{*}{ Village } & \multicolumn{8}{|c|}{$\%$ of trees per land use system } \\
\hline & & \multicolumn{2}{|c|}{ Cocoa farm } & \multicolumn{2}{|c|}{ Forest } & \multicolumn{2}{|c|}{ Homegarden } & \multicolumn{2}{|c|}{ Food crop field } \\
\hline & & I w & Ig & I w & $\mathrm{Ig}$ & $\mathrm{I} \mathrm{w}$ & $\mathrm{Ig}$ & I w & Ig \\
\hline \multirow[t]{3}{*}{ Centre } & Nkom I & 0 & 0 & 0 & 0 & 27 & 0 & 82 & 100 \\
\hline & Elig-Nkouma & 57 & 82 & 0 & 0 & 0 & 0 & 43 & 18 \\
\hline & Ngoumou & - & 27 & - & 19 & - & 1.5 & - & 52 \\
\hline $\mathrm{C}$ average & & 21 & 45 & 0 & 12 & 16 & 0.9 & 58 & 42 \\
\hline \multirow[t]{3}{*}{ East } & Dongo & 0 & 1.9 & 50 & 56 & 0 & 0 & 50 & 42 \\
\hline & Bouno & 2 & 0 & 98 & 100 & 0 & 0 & 0 & 0 \\
\hline & Gribi & 1.5 & 4 & 94 & 96 & 1.5 & 0 & 3 & 0 \\
\hline E average & & 1.6 & 1.6 & 93 & 91 & 0.8 & 0 & 4 & 7 \\
\hline \multirow[t]{3}{*}{ South } & Bidjap & - & 31 & - & 44 & - & 0.6 & - & 24 \\
\hline & Nko'ovos II & - & 22 & - & 2 & - & 7 & - & 68 \\
\hline & Ondodo & - & 26 & - & 19 & - & 0.9 & - & 54 \\
\hline$S$ average & & - & 26 & - & 19 & - & 4 & - & 51 \\
\hline \multirow{3}{*}{ Southwest } & Ossing & 65 & 44 & 7 & 23 & 3 & 0.8 & 24 & 32 \\
\hline & Kembong & 84 & 58 & 0 & 0.9 & 0.3 & 1.8 & 16 & 39 \\
\hline & Besong-Abang & 65 & 52 & 0 & 3 & 8 & 1.6 & 27 & 49 \\
\hline Sw average & & 75 & 49 & 1.8 & 12 & 3 & 1.3 & 20 & 38 \\
\hline Overall average & 70 & 36 & 7 & 26 & 3 & 2 & 19 & 36 & \\
\hline
\end{tabular}

\section{Start:}

Presence of Irvingia wombolu and Irvingia gabonensis trees in farmlands: The highest number of I. wombolu trees per household was found in the Manyu Division villages in Southwest Province (Table 3), where farmers have planted the species mainly in their cocoa and coffee farms (75\% of trees) and to a lesser extent in food crop fields (20\%; Table 4). Households in the East Province mainly collect I. wombolu fruits from the forest $(93 \%)$. Here, very few trees are found in farmers' fields. Only 15 and $25 \%$ of the households in Elig-Nkouma and Nkom respectively dispose of dry season bush mango trees in their farms and those who do, have them only in small numbers (maximum of 2 or 3 trees per household). It is worthwhile noting here that the sites in Centre Province are characterized by high demographic pressures on land. Contrasting with the Southwest province where farmers planted Irvingia trees, most trees in Centre and East provinces were retained when opening up forests for cocoa farms or food cropping.
The same trend as for I. wombolu can be found for I. gabonensis. Households in the Southwest have on average more I. gabonensis trees on their farm than their counterparts in other provinces. However, an average number of 16 I. gabonensis trees per household was recorded in Nko'ovos II, which approximates the amount found in the Southwest Province. Clear differences can be found in the distribution of $I$. gabonensis per land use system (Table 4). Contrary to $I$. wombolu, I. gabonensis seems to be less planted or retained in cocoa-farms. Overall, I. gabonensis trees are more often found in food crop fields (36\% against 20\% for I. wombolu), cocoa farms (36\%) and also most frequently collected from the forest (26\% against $7 \%$ ). Looking at the distribution per province, the difference is most striking in the Southwest province [where $I$. wombolu is mostly planted (cocoa farms) and $I$. gabonensis retained when opening up forest for food cropping] and not really apparent in East province, where people continue to collect most of the produce, whether I. wombolu or I. gabonensis from the forest. 
However, the amount of I. gabonensis trees located in cocoa-farms $(45 \%)$ is almost the same as that found in food crop fields (42\%) in the Centre province.

Extraction and storage of kernels: All the households with $I$. wombolu trees in their fields extract the kernels in periods of abundance. A few of them, however, have no kernels to extract in periods of scarcity (Table 4). Households in the Eastern Province, which mainly rely on forest resources for the extraction of kernels, seem to be more vulnerable than those of the Southwest that have I. wombolu trees on their farms. The results in Table 4 show that, on average, $25 \%$ of the households in East Province do not extract kernels in periods of scarcity against only $2 \%$ in the Southwest Province. The total number of trees per household is also a determining factor. The more trees a household has, the less vulnerable it will be two years of low production.

Except for Elig-Nkouma, where 12\% of households with I. gabonensis in their fields eat the fresh fruits and throw away the nuts, all the other households extract the kernels in periods of abundance (Table 4). Households in the Centre and South provinces seem to be more affected by bad production. For example, 65 and $57 \%$ of households in Ngoumou and Elig-Nkouma respectively do not extract $I$. gabonensis kernels in that period against 0\% in Ossing and Kembong.

At least half and $70 \%$ of the farmers who extract $I$. wombolu and I. gabonensis kernels respectively preserve part of their harvest. Overall, the percentage of households that store I. wombolu kernels were found to be higher $(\mathrm{P}=0.003)$ in periods of abundance $(88.8 \%)$ than in periods of scarcity $(84.7 \%)$ while this percentage was not found to be significantly different in periods of abundance and scarcity for $i$. gabonensis $(97$ and $96 \%$ respectively). Interestingly, although the number of $I$ wombolu trees per household in the Southwest (36) differs from that of I gabonensis (18; Table 4), the quantity of kernels extracted and preserved for both species is the same (Table 4) in each period. This indicates the importance of both species for farmers all year round, as their fruiting period differs. In the Centre and East provinces, the volume of I wombolu kernels extracted and preserved is lower than that of I gabonensis. This is probably due to the very low number of $I$. wombolu trees compared to that of I gabonensis. The importance of I. wombolu in the Southwest could be due to the preferences of Nigerian traders, because this species fetch high prices in crossborder markets ${ }^{[11]}$.

Methods of preservation: In all sites, the most common storage place is a platform of bamboo rack hung over a fireplace in the kitchen. Preservation methods were found to be similar for the two species, although more methods were recorded for I. gabonensis (29) as compared to I. wombolu (17). Some methods were found only in specific areas, such as nuts stuck on mud walls in the Southwest and cakes wrapped with leaves in the East and South (Fig. 1 and 2). Other storage methods occur in many areas, like sun drying of kernels and cake wrapped in leaves. I. gabonensis seed cakes are made in the East, South and Ossing (Southwest) while I. wombolu ones are exclusively made in the Eastern province. The process consists of roasting and grinding the kernels. The paste that is obtained in this way is put in a cake tin (container) and left to dry for a few hours. Once solid, the cake is removed from the container and is ready for use. In the village of Gribi, women place a tin below the grid on which I. gabonensis cake is stored, to collect the oil that drips from its running. This oil is used in cooking.

Duration of storage: A $22 \%$ of the interviewed households reported they preserved I. wombolu kernels for more than a year and very few $(1.9 \%)$ for two years. During the survey, however, no samples of kernels or cake older than one year were found in any of the study sites. This suggests that farmers rarely manage to satisfy their household consumption needs of $I$. wombolu throughout the year and many farmers stated that after 6-8 months preservation, I. wombolu kernels tasted soapy, making them undesirable for consumption. The duration of storage reported most frequently ( $78 \%$ of households preserving I. wombolu kernels) are 6 months to less than one year for all the methods recorded.

Amongst all the methods recorded to preserve $I$. gabonensis kernels in the Southwest, $70 \%$ of households reported that they could not store $I$. gabonensis for more than one year. In the East, I. gabonensis cakes stored on a bamboo rack hung over the fireplace were found to preserve the kernels longest:

$62 \%$ of the households using this method reported preserving kernels for more than one year (with 32\% for more than 18 months).

\section{CONCLUSION AND RECOMMENDATIONS}

During the survey farmers stated that they are rarely able to preserve sufficient good quality (not rotten and tasteful) kernels to meet their household needs throughout the year. The principal idea behind the choice of storage method is to avoid the humidity that leads to deterioration in the quality of the kernels. The diversity found in indigenous practices for preserving bush mango kernels indicates the degree of farmers' knowledge and their experience in preserving Irvingia spp. Kernels. However, there is a need to develop methods of preservation that allow long-term storage (more than 1 year) without reducing the nutritive value and sensory attributes. The best approach to develop these techniques would be to build upon the existing local knowledge. 


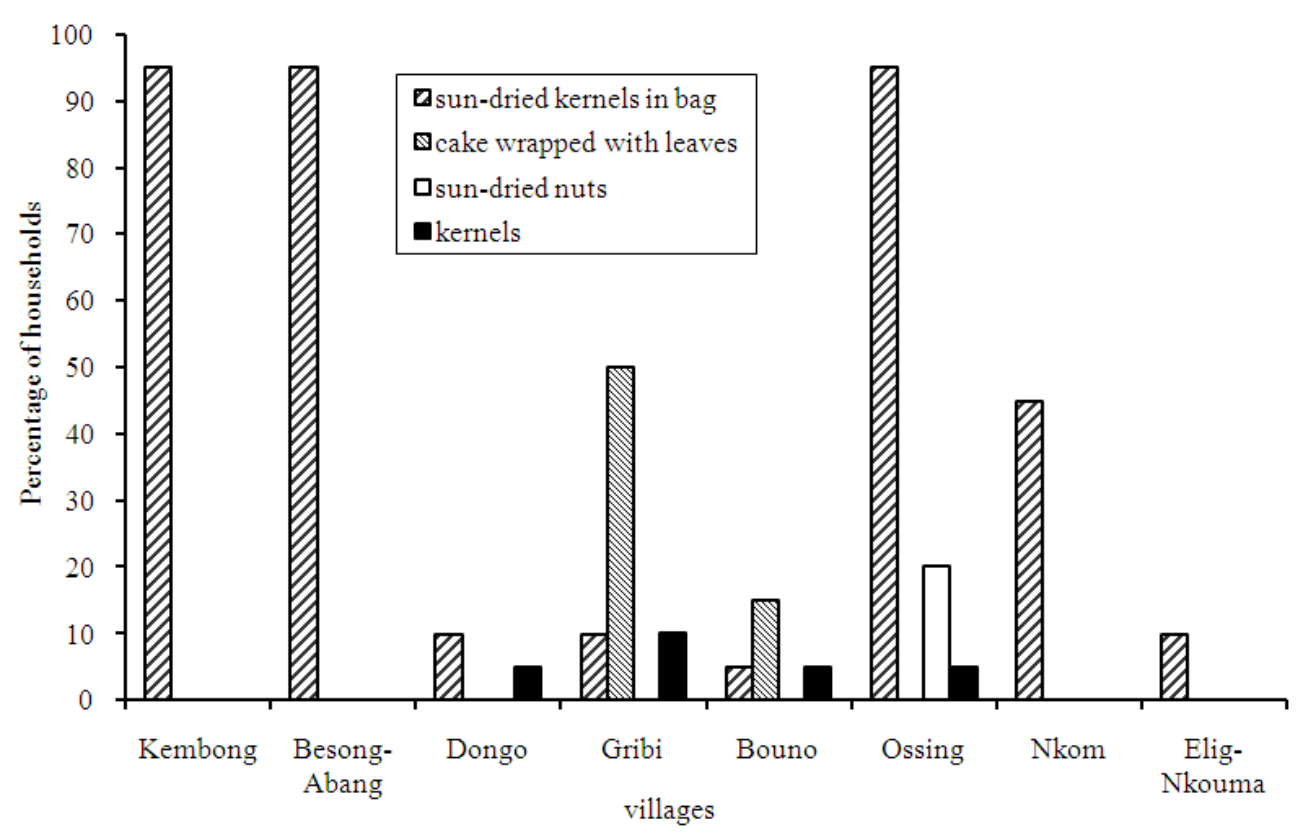

Fig. 1: Main preservation methods of Irvingia wombolu nuts and kernels in the Southern Cameroon
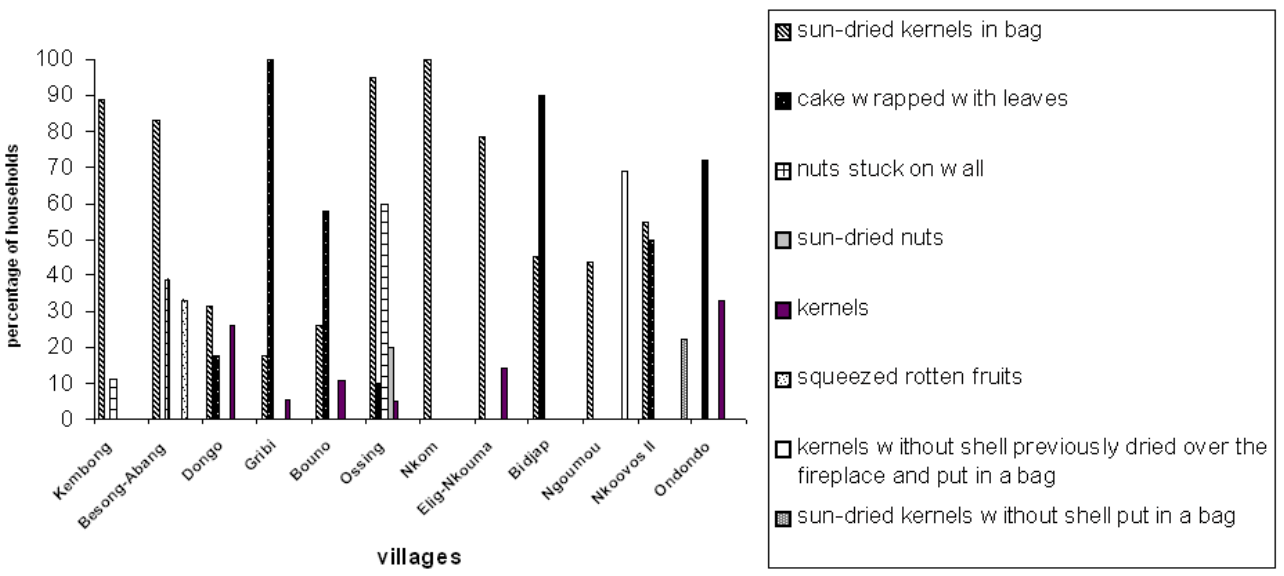

Fig. 2: Main preservation methods of Irvingia gabonensis nuts and kernels in the Southern Cameroon

A drying rack made of bamboo (Bambusa vulgaris) hung over a fireplace in the kitchen emerged as the most frequent storage place. This clearly indicates that cold and humidity are to be avoided during storage of bush mango kernels. Continuously heating kernels and kernel by-products certainly lowers moisture content, reducing fungal infection and insect attacks both of which affect kernel quality. Smoke could also have a disinfecting effect on kernels and cakes. However, drying and heating off the kernels also affects their quality in other ways, such as color, odor, sliminess and nutritive value ${ }^{[16]}$. Results from this study indicate that further investigation is needed to:

* The duration of preservation of I. wombolu and I. gabonensis kernels and its impact on their nutritional value;
* The optimum temperature for preserving bush mango seeds and cakes without reducing their sensory and nutritive attributes.

\section{ACKNOWLEDGEMENTS}

This publication is an output from a research project funded by the United Kingdom Department for International Development (DFID) for the benefit of developing countries. The views expressed here are not necessarily those of DFID (R7190 Forestry Research Program). The authors are indebted to DFID for funding this project and wish to thank Dr Kate Schreckenberg (Overseas Development Institute, London) for her help and the useful comments made on an earlier version of this paper. Also acknowledged are Ms Liz Betser, MM Ebenezer Asaah and Peter Mbile 
(ICRAF West Africa) and all the farmers who were interviewed during this study.

\section{REFERENCES}

1. Sanchez, P.A. and R.R.B. Leakey, 1997. Land use transformation in Africa: Three determinants for balancing food security with natural resource utilization. Eur. J. Agron., 7: 15-23.

2. Leakey, R.R.B., Z. Tchoundjeu, K. Schreckenberg, S.E. Shackleton and C.M. Shackleton, In press. Agroforestry Tree Products (AFTPs): Targeting Poverty Reduction and Enhanced Livelihoods. Intl. J. Agril. Sustainability.

3. Leakey, R.R.B. and H. Jaenicke, 1995. The domestication and commercialization of indigenous fruit trees: opportunities and challenges for Agroforestry. Proc. 4th Intl. BIO-REFOR Workshop. K. Suzuki, S. Sakurai, K. Ishii and Norisada (Eds.), pp: 15-26, BIO-REFOR, Tokyo, Japan.

4. Simons, A.J. and R.R.B. Leakey, 2004. Tree domestication in tropical Agroforestry. Agroforest. Systems, 61: 167-181.

5. Franzel, S., H. Jaenicke and W. Janssen, 1996. Choosing the right trees: Setting priorities for multipurpose tree improvement. ISNAR Research Report 8, pp: 87.

6. Harris, D.J., 1996. A revision of the Irvingiaceae in Africa. Bulletin du Jardin Botanique National de Belgique, 65: 143-196

7. Okafor, J.C., 1975. Varietal delimitation in Irvingia gabonensis (Irvingiaceae). Nigerian J. Forest., 4: 80-87.

8. Okafor, J.C. and G. Ujor, 1997. Varietal differences in Irvingia gabonensis. Bush Mango and Close Relatives. Proceedings of a West African Collection Workshop held in Ibadan, Nigeria. Ladipo, D.O. and Boland, D. (Eds.), pp: 5-10 ICRAF, Nairobi, Kenya.

9. Atangana, A.R., Z. Tchoundjeu, J.M. Fondoun, E. Asaah, M. Ndoumbe and R.R.B. Leakey, 2001. Domestication of Irvingia gabonensis: 1. Phenotypic variation in fruits and kernels in two populations from Cameroon. Agroforest. Systems, 53: 55-64

10. Agwu, C.O.C. and T.O. Akanbi, 1985. A palynological study of honey from four vegetation zones of Nigeria. Pollen and Spores, 27: 335-348.
11. Okafor, J.C., 1981. Woody plants of nutritional importance in the traditional farming systems of the Nigerian humid tropics. Ph.D. Thesis. Univ. of Ibadan, Nigeria.

12. Ayuk, E.T., B. Duguma, S. Franzel, J. Kengue, M. Mollet, T. Tiki-Manga and P. Zekeng, 1999. Uses, management and economic potential of Irvingia gabonensis in the humid lowlands of Cameroon. Forest Ecol. and Manag., 113: 1-9.

13. Ndoye, O., 1995. The markets for non-timber forest products in the humid forest zone of Cameroon and its borders: Structure, conduct, performance and policy implications. Center for Intl. Forest Res. (CIFOR), Bogor, Indonesia.

14. Ndoye, O., M. Ruiz-Perez and A. Eyebe, 1997. The markets of non-timber forest products in the humid forest zone of Cameroon. Rural Develop. Forest. Network Paper, 22c, ODI, London.

15. Joseph, J.K., 1995. Physico-chemical attributes of wild mango (Irvingia gabonensis) seeds. Biores. Tech., 53: 179-181.

16. Leakey, R.R.B., 1999. Potential for novel food from Agroforestry trees: A review. Food Chem., 66: 1-14.

17. Ejiofor, M.A.N., S.N. Onwubuke and J.C Okafor, 1987. Developing improved methods of processing and utilization of the kernels of Irvingia gabonensis (var. gabonensis and var. excelsa). Int. Tree Crops J., 4: 283-290.

18. Leakey, R.R.B., P. Greenwell, M.N. Hall, A.R. Atangana, C. Usoro, P.O. Anegbeh, J-M. Fondoun and Z. Tchoundjeu, 2005. Domestication of Irvingia gabonensis: 4. Tree-to-tree variation in food-thickening properties and in fat and protein contents of dicka nut. Food Chem., 90: 365-378.

19. Kengni, E., 2003. Food value of fruits from indigenous fruit trees in the lowland humid tropics of west and central Africa: case of Irvingia gabonensis and Dacryodes edulis in Cameroon. Ph.D. Thesis. Univ. of Yaoundé I, Cameroon, pp: 259.

20. Schreckenberg, K., R.R.B Leakey and Z. Tchoundjeu, 2000. Opportunities and constraints faced by resource-poor farmers in investing in the planting and improvement of indigenous trees for income generation. Eur. Trop. Forest. Res. Network Newslett., 32: 53-55. 